\title{
Comparative analysis of the economic returns to management in single crop, fish, poultry and an integrated farming system in Obudu, Cross River State
}

\author{
Ugbe, Lawrence A., Ukelina, Christopher U., Agim, Marcel U., and Unim, Mathias U. \\ Federal College of Education, Obudu, In Affiliation with the University of Calabar, Calabar Nigeria \\ Correspondence e-mail: ugbeahmed@gmail.com
}

\begin{abstract}
A four year $(2016,2017,2018$, and 2019) field experiment was conducted to compare the economic returns to investment in single enterprise with integrated farming comprising of rice farm alongside with fish culture and poultry farm using mostly organic waste as feeds. In 2016 a rice farm was cultivated on a piece of land already procured for the experiment, fertilizers, herbicides and pesticides were all applied. At maturity the rice was harvested, processed, bagged in $100 \mathrm{~kg}$ bags and sold. Economic returns to management were calculated according to the methods of CIMMYT, (1988). In 2017, only fish farm was established, fed and harvested at maturity and sold to consumers. Economic returns to management were also calculated and recorded. In 2018, a poultry farm was established, 200 broilers were reared to maturity and sold, economic returns to management were calculated and recorded. Then in 2019, an integrated farm comprising rice farm, fish farm and poultry farm were all established in the same field. About $70 \%$ of the feeds used were organic waste collected mostly from poultry droppings. The silt from the pond was also used as fertilizer for the rice farm, while the rice bran was also fed to the poultry. The output from the farms were harvested and sold, and the economic returns to investment for each farm calculated. The result showed that the returns to investment were significantly $(\mathrm{p}<0.05)$ higher in integrated farming system than in the single enterprise farm, due to the low cost of production using low cost inputs in integrated farming compare to the use of high cost synthetic inputs in single enterprise. The paper therefore recommended that farmers should adopt integrated farming system with low cost inputs for higher profit than the single enterprise farming.
\end{abstract}

Keywords: Economic returns, Integrated farming, single enterprise, recycling, utilization of resources

\section{Introduction}

Rice is the most cultivated cereal in the world, over 150 to 180 million hectares (Udoh, Udon, Asuquo and Ndaeyo, 2005). It is a staple food for over $50 \%$ of the world's population. In Nigeria, the per-capita consumption of rice in the $1980 \mathrm{~s}$ was $18 \mathrm{~kg}$ and rose to $22 \mathrm{~kg}$ between 1995 and 2000 in 2005, the average per-capital consumption was $24-28 \mathrm{~kg}$ and double in 2015 to $56 \mathrm{~kg}$ (FAO, 2008). In fact, rice is an indispensable crop in the strategy for food security in subSaharan Africa, because it provides $27 \%$ of the energy and $20 \%$ of the protein needs in developing countries including African countries (FAO, 2008).

In sub-Saharan Africa, and indeed in West Africa, Nigeria is the leading producer and consumer of rice, accounting for $64.20 \%$ and $61.90 \%$ of total production and consumption respectively (FAO, 2008). On the whole, total rice consumption in Nigeria in recent times stands at 5.4 million tonnes annually, while output is about 3.8 million tonnes (National Bureau of Statistics-NBS, 2018). Apart from direct use as food, rice is also used in maing alcohols, starch, oils, pharmaceutical products and dietetic food.

Fish is of both primary and secondary importance to man. The primary importance of fish is in its usage as food by man. It provides high quality protein in humans and livestock diets. It is one of the cheapest sources of animal protein demanded for consumption throughout the world and it contains balanced amino acid needed for rapid growth in humans (Carballo, Van Ecr, Schie, Tonvan, Hibbrands and Odey, 2018).

Nigerians are high fish consumers with a total current consumption of about 1.2 million tonnes per year, out of which about 60 $\%$ is imported (Federal Ministry of Agriculture and Rural DevelopmentFMARD, 2007). Nigerian's total fish supply 
Ugbe, Lawrence A., Ukelina, Christopher U., Agim, Marcel U., and Unim, Mathias U.:

Comparative analysis of the economic returns to management in single crop, fish, poultry and an integrated farming system in Obudu, Cross River State

was 1,160,000 metric tonnes in 2004 (FMARD, 2007). Nigeria is the highest importer of fish and fishery products in Africa. The total domestic fish production in 2007 stood at an estimated 600,000 MT, while importation was estimated at over 700,000 MT (FMARD, 2007). Nigeria's demand for fish in 2010 was projected at 1.89 million tonnes, however, the actual production was 800,000 million metric tonnes. The fish supply gap deficit was over one million metric tonnes (FMARD, 2011). Considering that the population growth rate of Nigeria is $3.0 \%$ the fish supply gap deficit is expected to continuously increased (Aquaculture and Inland Fisheries ProjectAIFP, 2011). The current global average annual consumption is about $13.5 \mathrm{~kg} /$ year, if Nigeria targets the amount, the total demand will be $20 \%$ more than the forecasted demand (AIFP, 2011)

Poultry plays significant role in human economy, through provision of food, while creating wealth through the provision of jobs for the teeming population (Alder, Costa, Galleard, Sparks and Zhou, 2019). Also, the poultry industry provides economic support and development effect on the tourism sector as well as the fashion industry. The nutritional benefits derived from poultry products such as animal proteins, minerals, fat-soluble vitamins, carbohydrates, pigments, fluids, and cholesterol is attributable to its relevance as the world major source of food (Dilger, Schroeder and Moseley, 2016). It is also relevant in industrial uses in the provision of vaccines, fertilizers, animal feeds, pharmaceutical products including preservatives during semen storage, in paint and adhesives, varnishes, printers ink etc (Wahyono and Utami, 2018).

Nigeria's poultry population at present, stands at 180 million birds (FAO, 2018). This shows a substantial increase from about 151 million birds few years back. Global production of poultry as at 2011 and
2016 was over 50 billion and 66 billion poultry birds respectively (FAO, 2018). This number dropped to 23 billion birds by 2018 due to the outbreak of Avian influenza (H5NI) and mutation strains in China which affected over $13.6 \%$ of the world poultry supply (FAO, 2018). It has been estimated that by 2030 , the demand for poultry products across Africa will increase by $60 \%$ especially in Nigeria, which is the largest market for poultry products in Africa (World Economic Forum, 2019. Statistics show that the present consumption across the African continent is almost 100 million tonnes for both poultry meat and egg products, whereas in Nigeria, 192.6 metric tonnes are consumed annually (Ritchie and Roser, 2020).

Integrated farming system is a concept which explains the cultivation of crops, fish and rearing of livestock at the same time either in the same field or closer fields. In Nigeria, integrated fish farming has been in practice in many states of the federation in which $50 \%$ of fish farmers integrate poultry, piggery or livestock with fish production, while integrated fish cum crop production is on the rise also in several states (Aquaculture and Inland Fisheries Project-AIFP, 2005). According to Asala (1994) the need for an integrated system is to increase productivity in order to meet the challenges of food shortage and reducing the rate of unemployment in the country. In considering an integrated farming system, the socioeconomic conditions of the country must be given priority. This is because the development of a diversified economy depends on the harmonious interactions between socio-economic condition, agricultural productions and regional environmental conditions (Huazhu and Boatang, 1989). Ayinla (2003) observed that in any part of the country the type and level of integration depends on the prevalent environmental conditions, social norms, cultural values and religious factors. $\mathrm{He}$ 
Ugbe, Lawrence A., Ukelina, Christopher U., Agim, Marcel U., and Unim, Mathias U.:

Comparative analysis of the economic returns to management in single crop, fish, poultry and an integrated farming system in Obudu, Cross River State

added that for example, in northern part of the country where eating pork is a taboo due to religious beliefs a fish cum pig integration is not advisable. The agricultural enterprise to be combined and their level of intensity determine the type of integration.

Nnaji, Okoye, and Oganseye (2003) reported that fish farming integrated with the cultivation of agricultural crops such as vegetables, and arable crops like rice, maize etc and aquatic plants such as water spinach, water chestnut, aquatic weeds like pistia, duck weed, water hyacinth, Azolla etc is widely practiced among farmers in the rural areas at subsistence level. They added that in the case of fish integrated with rice, the rice is planted right inside the pond. The crops derive water and nutrients from the fish ponds while the crop serves as food, especially for herbivorous fish. Beside, periphytons on the crop may enhance yield of cultured fish species.

The population of people living in Nigeria has risen tremendously in recent years with its corresponding increase in the demand for food. Therefore there is the need for a suitable agricultural system to meet this increasing demand and also maximize the utilization of the available limited resources without much wastage. Integrated farming may offer hope in this direction.

Many farmers in Obudu cultivate only rice, or rear poultry or pigs only or cultivate fish only in a particular time whenever they plan to go into commercial agriculture, with this, they depend on synthetic inputs in production and at the same time waste organic materials that should have been recycle in an integrated farming system for higher productivity. This is the focus of this paper. The specific objectives of this research were to:

i. Determine the economic returns to management in a single enterprise like rice only, poultry only, or fish culture only.

ii. Determine the economic returns to management in an integrated farming system-rice, poultry and fish established at the same time in the same place.

iii. Analyse and compare the economic returns to management in the single enterprise and in the integrated crop, fish and poultry farming based on the prevalent prices of the output and the resources applied in the production.

\section{Materials and methods}

The experiment was conducted in four years; 2016, 2017, 2018 and in 2019. A piece of land measuring one lecture $(10,000 \mathrm{sqm})$ was procured, $70 \%$ of the down part of the land was a swampy area, while the upper part was upland. In 2016, single crop (Rice) was cultivated, while in 2017 only poultry birds (Broilers) were reared to table size and sold after 8 to 10 weeks. In 2018, four fish ponds were constructed and fish rearing was the only investment in the year. In 2019 an integrated farm comprising rice, poultry and fish rearing was established.

In 2016, the swampy part of the land was cleared, on the $5^{\text {th }}$ of July, the trash were packed and burnt. Soil analysis was conducted by taking samples of the soil to the laboratory to determine the fertility status of the soil. The land was ploughed on the $12^{\text {th }}$ of June and then pulveriesed three days later to give a fine titlth. NKP fertilizer at $300 \mathrm{~kg} / \mathrm{ha}$ was applied before the planting of the rice seedlings which took place on the $15^{\text {th }}$ of June 2019. Rice seedlings which were prepared in nursery six weeks earlier, were transplanted to the field. At about eight weeks after transplanting, selective herbicides (Basagram PL) was applied round the field at $3.36 \mathrm{~kg} / \mathrm{ha}$ to keep weeds off the farm, while hand 
Ugbe, Lawrence A., Ukelina, Christopher U., Agim, Marcel U., and Unim, Mathias U.:

Comparative analysis of the economic returns to management in single crop, fish, poultry and an integrated farming system in Obudu, Cross River State

weeding was done inside the rice farm to also keep weeds off the rice farm. At flowering and fruiting, an insecticide-Basudin (Diazinon at $20 \mathrm{ml}$ conc. In 18 liters of water/ha) was applied to control insect pests alongside with bird scaring to keep the activities of quelea quelea birds away from the rice farm. At maturity, the rice was harvested, threshed, winnowed and bagged for sale in the market. After selling, the economic returns to management were calculated based on the prevalent cost per $100 \mathrm{~kg}$ bag of rice in the market which was seventy thousand naira (N70,000.00) a bag.

In 2017, the same piece of land was cleared and trash burnt. Five natural ponds were constructed on the swampy part of the field. Each pond was $4 \mathrm{~m} \times 9 \mathrm{~m}$ with the embankment made of mud, with water standing inside each pond. The ponds were separated by five metres apart. Two thousand five hundred $(2,500)$ fingerlings of cat fish were procured at thirty naira $(\mathrm{N} 30.00)$ per fingerling totaling seventy five thousand naira (N75,000.00) only. The fingerlings were stocked at 500 per pond. Feeds $(1.5 \mathrm{~mm}$ and $2.00 \mathrm{~mm}$ ) were procured, later $6.00 \mathrm{~mm}$ and $9.00 \mathrm{~mm}$ were also procured at 14 to 16 weeks of the fingerlings. Mortality was $2.0 \%$ (50 fingerlings). The fish were sold at six to eight months at the rate of one thousand two hundred naira $(\mathrm{N} 1,200)$ per kilogramme weight of fish. The returns to investment were calculated based on the prevalent price of $\mathrm{N} 1,200$ per kilograme and the quantity of fish sold.

In 2018, a poultry house was constructed on the upland side of the field. Two hundred and fifty (250) birds (Broilers) at day old were procured and stocked in the poultry house. The birds cost seven hundred naira (N700.00) per day old. The birds were fed to maturity with starter, grower and finisher marsh and sold out at eight to ten weeks, although some mortality of $8 \%$ was recorded. After selling, the economic returns to investment or management were calculated and the profit determined.

In 2019, an integrated farm comprising rice, poultry, and fish were established on the same piece of land. The ponds were stocked with 200 fingerlings each, giving a total of 1000 fingerlings in 5 ponds. 30 fingerlings died giving a mortality rate of $3.0 \%$ while rice was cultivated within and outside the ponds. The poultry house stocked with 200 of day old broilers was on the upland side of the field, 20 of the birds died giving a high mortality rate of $10 \%$. Also the inputs of the integrated farm were mainly organic waste recycling amongst the three farms. About 20,000 to $30,000 \mathrm{~kg}$ of silt produced in the ponds was enough to fertilizer the rice farm. The protein rich chicken droppings were supplied to the fish, the rice planted in and within the ponds were deriving water and nutrients from the fish ponds, while some smaller aquatic plants alongside with the periphytons and insects on the rice plants provided food for the fish in the ponds. When the fish were harvested and processed, some fish waste were processed and fed to the birds. The poultry droppings were also very good fertilizer to the rice farm. When the rice was harvested and processed, rice bran were fed to the birds. The whole process was a complementary enterprise development. The fish were harvested and sold at (N1,200 per kilo) the rice was harvested and sold at (N70,000 per $100 \mathrm{~kg}$ ) and the poultry birds sold at N4000 per bird. The economic returns to investment or management was calculated for each of them and the profit or lose determined. The economic returns to management for the single, enterprise were compared with the integrated enterprise based on the inputs used for production, in order to determine between the single enterprise with mainly synthetic inputs and the integrated enterprise with about $70 \%$ organic inputs, the one that is more profitable and cost effective. 
Ugbe, Lawrence A., Ukelina, Christopher U., Agim, Marcel U., and Unim, Mathias U.:

Comparative analysis of the economic returns to management in single crop, fish, poultry and an integrated farming system in Obudu, Cross River State

All data generated were computed for economic returns to investment using CIMMTY (1988) by subtracting Total Cost (TC) of production from Gross Revenue (GR) accruing from the production (i.e GR-TC) based on their prevailing market prices of the out puts (i.e rice, poultry, and fish). The returned to investment were compared at $(\mathrm{P}<0.05)$ level of significance.

\section{Results}

The soil which is swampy on the down part of it, is well-drained and sandy loam (Table 1) on the upland side of it. The soil is acidic and with good organic matter content. The Cation Exchange Capacity (CEC), Total nitrogen, Available $\mathrm{P}$ and Exchangeable $\mathrm{K}, \mathrm{Ca}$, and $\mathrm{Mg}$ were generally within acceptable ranges for sustainable crop production.

Table 1: Some physio-chemical properties of soil at the experimental site before planting

\begin{tabular}{|c|c|c|c|c|c|}
\hline \multicolumn{2}{|c|}{ Soil Properties } & 2016 & 2017 & 2018 & 2019 \\
\hline 1. & Soil $\mathrm{P}^{\mathrm{H}}\left(\mathrm{H}_{2} \mathrm{O}\right)$ & 5.65 & 5.32 & 5.63 & 5.50 \\
\hline 2. & Organic matter (\%) & 2.70 & 2.52 & 2.60 & 2.35 \\
\hline 3. & Total Nitrogen (\%) & 0.22 & 0.22 & 0.20 & 0.18 \\
\hline 4. & Available P (mg/kg) & 158.33 & 142.21 & 168.50 & 158.20 \\
\hline 5. & Exchangeable cation & & & & \\
\hline i. & $\mathrm{Ca}(\mathrm{Meg} / 100 \mathrm{~g})$ & 4.80 & 3.20 & 5.70 & 5.52 \\
\hline ii. & Mg (Meg/100g) & 2.23 & 2.20 & 2.52 & 2.55 \\
\hline iii. & $\mathrm{Na}(\mathrm{Meg} / 100 \mathrm{~g})$ & 0.06 & 0.06 & 0.05 & 0.05 \\
\hline iv. & K (Meg/100g) & 0.21 & 0.22 & 1.06 & 1.05 \\
\hline 6. & Exchangeable acidit & & & & \\
\hline i. & $\mathrm{Al}(\mathrm{cmol} / \mathrm{kg})$ & 0.60 & 0.52 & 0.58 & 0.40 \\
\hline ii. & $\mathrm{H}(\mathrm{cmol} / \mathrm{kg})$ & 0.41 & 0.40 & 0.42 & 0.22 \\
\hline iii. & $\mathrm{ECEC}(\mathrm{cmol} / \mathrm{kg})$ & 8.32 & 6.54 & 10.32 & 9.46 \\
\hline 7. & Particle size distribu & & & & \\
\hline i. & Sand & 86.60 & 89.62 & 89.50 & 88.69 \\
\hline ii. & Silt & 5.52 & 5.65 & 5.50 & 5.32 \\
\hline iii. & Clay & 4.92 & 4.72 & 4.92 & 4.91 \\
\hline iv. & Soil texture & Sandy loam & & & \\
\hline
\end{tabular}


Ugbe, Lawrence A., Ukelina, Christopher U., Agim, Marcel U., and Unim, Mathias U.:

Comparative analysis of the economic returns to management in single crop, fish, poultry and an integrated farming system in Obudu, Cross River State

Table 2: Cost of production of rice in 2016 and economic returns to management in naira per hectare (N/ha) as influenced by the different prices of inputs and the prevailing mark price of rice

\begin{tabular}{lll}
\hline S/N & Operation details & Cost \\
A & Cost of soil analysis production variables & $\mathrm{N} 25,000.00$ \\
B. & Production variables & $\mathrm{N} 10,000.00$ \\
i. & Land preparation & $\mathrm{N} 75,000.00(100 \mathrm{~kg})$ \\
ii. & Cost of planting materials (Paddy rice grains) & $\mathrm{N} 5,000.00$ \\
iii. & Cost of sowing at nursery (Broadcasting) & $\mathrm{N} 10,000.00$ \\
iv. & Cost of transplanting seedlings & $\mathrm{N} 25,000.00$ \\
v. & Cost of herbicides (5 containers, N5000 per bootle) & $\mathrm{N} 5,000.00$ \\
Vi & Cost of herbicide application & $\mathrm{N} 55,000(10,000$ per bag) \\
Vii & Cost of 5 bags of fertilizers/application & $\mathrm{N} 25,000.00(5000$ per bottle) \\
viii & Cost of 5 containers of insecticides & $\mathrm{N} 5,000,00$ \\
ix. & Cost of insecticide application & $\mathrm{N} 6,000.00$ \\
$\mathbf{X}$ & Cost of harvesting & $\mathrm{N} 6,500.00$ \\
xi. & Cost of processing & $\mathrm{N} 50,000.00$ \\
xii. & Miscellaneous & $\mathbf{N 3 0 3 , 5 0 0 . 0 0}$ \\
C & Total cost (TC) & $200 \mathrm{~kg}$ \\
D. & Yield in kilograms & $400 \mathrm{~kg} / \mathrm{ha}$ \\
$\mathbf{E}$ & Yield in kg/ha & $\mathrm{N} 600,000.00$ \\
$\mathbf{F}$ & Gross Revenue (GR) & $\mathrm{N} 297,500.00$ \\
$\mathbf{G}$ & Returns to management (GR-TC) & 1.9. \\
H & Benefit cost Ratio (GR/GC) & \\
\hline
\end{tabular}

(a) Miscellaneous cost are expenses on feeding, weeding and transportation

(c) Gross revenue $=$ yield $(\mathrm{kg} / \mathrm{ha}) \mathrm{x}$ unit price of fifteen thousand naira $(\mathrm{N} 15,000)$ per bag of $100 \mathrm{~kg}$ bag of milled rice

(d) Yield in $\mathrm{kg} / \mathrm{ha}$ is 10,000 sqm (1heatare) $\quad \mathrm{x} \quad$ plot yield in $\mathrm{kg}$

Plot area in sq (100x 50m)

Table 2: shows economic returns to management in naira per hectare of rice as influenced by market price of $100 \mathrm{~kg}$ bag of rice. The total cost of production of the rice was put at three hundred and two thousand five hundred naira (N302,500.00), while economic returns to management was two hundred and ninety seven thousand, five hundred naira (N297.500.00). The economic returns to management was not significant $(\mathrm{P}>0.05)$ since it was less than the total cost of production.

Table 3 shows economic returns to management in kilogrammes weight/tonue of fish as influenced by the market price of the inputs and the unit cost ( $\mathrm{kg} /$ tonne) of fish.
The economic returns to management was not significant $(\mathrm{P}>0.05)$ as the cost of production was far greater than the income (a deficit budget).

Table 4 shows the computed economic returns to management or investment for poultry production in the year 2018. The economic returns to management was not significance $(\mathrm{P}>0.05)$ as the cost of production far outweighs the returns to investment. The total cost of production was one million, one hundred and forty four thousand naira $(\mathrm{N} 1,144,000.00)$, while the returns were only minus four hundred and forty four thousand naira (N-444,000.00 only. This also was a deficit budget. 
Ugbe, Lawrence A., Ukelina, Christopher U., Agim, Marcel U., and Unim, Mathias U.:

Comparative analysis of the economic returns to management in single crop, fish, poultry and an integrated farming system in Obudu, Cross River State

Table 3: Cost of production of fish in 2017 and economic returns to management in kilogrammes weight/tone. As influenced by the prices of inputs used and the prevailing market price of a kilogram of fresh fish

\begin{tabular}{|c|c|c|}
\hline $\mathbf{S} / \mathbf{N}$ & Production variables & Cost \\
\hline 1 & Cost of construction of five natural ponds (at N2000 per pond) & $\mathrm{N} 10,000.00$ \\
\hline a. & Cost of procurement of 2500 fingerlings (at 30 per fingerling) & $\mathrm{N} 75,000.00$ \\
\hline b. & Cost of feeds & \\
\hline i. & 20 bags of $1.5 \mathrm{~mm}$ (at N5000 per bag) & N100,000.00 \\
\hline ii. & 20 bags of $2.0 \mathrm{~mm}$ (at N6,500 per bag) & N130,000.00 \\
\hline iii. & 50 bags of $6.0 \mathrm{~mm}$ (at N7000 per bag) & N350,000.00 \\
\hline iv. & 100 bags of $9.0 \mathrm{~mm}$ (at $\mathrm{N} 8000$ per bag) & $\mathrm{N} 800,000.00$ \\
\hline 2. & Cost of nest & $\mathrm{N} 3,000.00$ \\
\hline 3. & Miscellaneous & N50,000.00 \\
\hline 4. & Total cost & $\mathrm{N} 1,608,000.00$ \\
\hline 5. & $\begin{array}{l}\text { Gross Revenue (GR) 2, } 450 \text { fish gave } 816,66 \mathrm{~kg} \\
816.66 \text { x N1,200) per kilo }\end{array}$ & N979,992.00 \\
\hline 6. & Returns to investment (GR - TC) & $\begin{array}{l}\text { N-628,008.00 } \\
\text { (deficit) }\end{array}$ \\
\hline 7. & Benefit cost ratio $(\mathrm{GC} / \mathrm{TC})$ & 0.06 \\
\hline
\end{tabular}

Table 4: cost of production of broilers (birds) in 2018 and economic returns to management in kilogrammes weight/tonne as influenced by the prices of inputs used and the prevailing market price of broilers

\begin{tabular}{|c|c|c|}
\hline $\mathbf{S} / \mathbf{N}$ & Operation DETAILS & Cost \\
\hline & Production variables & \\
\hline 1. & Cost of construction of the poultry house & \\
\hline a. & Zinc ( 10 bundles, at N18,000.00 per bundle & $\mathrm{N} 180,000.00$ \\
\hline b. & Nails & N60,000.00 \\
\hline c. & Wood & $\mathrm{N} 80,000.00$ \\
\hline D & Wire nets & N56,000.00 \\
\hline e. & Cement (at N2,000 per bag for 8 bags) & $\mathrm{N} 16,000.00$ \\
\hline f. & Sand (at N8,000 per trip for 5 trips) & $\mathrm{N} 40,000.00$ \\
\hline g. & Workmanship & $\mathrm{N} 20,000.00$ \\
\hline i. & Non consumables & \\
\hline a. & Drinkers (at N800,00 per drinker for 10 drinkers) & $\mathrm{N} 8,000.00$ \\
\hline b. & Brooders (at N1,500.00 per brooder for 5 brooders) & $\mathrm{N} 7,500.00$ \\
\hline c. & Feeders (at N650.00 per feeder for 10 feeders) & N6,500.00 \\
\hline d. & Cost of 250 day old chicks (at N700 per chick) & $\mathrm{N} 175,000.00$ \\
\hline 2. & Feeds & \\
\hline a. & Starter marsh (at N2,500 per bag for 56 bags) & $\mathrm{N} 140,000.00$ \\
\hline b. & Growers marsh (at N2,500 per bag for 56 bags) & $\mathrm{N} 140,000.00$ \\
\hline c. & Finishers marsh (at N3000 per bag for 56 bags & $168,000.00$ \\
\hline d. & Vaccines & $\mathrm{N} 15,000.00$ \\
\hline e. & Saw dust & $\mathrm{N} 2,000.00$ \\
\hline 3. & Miscellaneous & $\mathrm{N} 30,000.00$ \\
\hline 4. & Total cost (TC) & $\mathrm{N} 1, \mathbf{1 4 4 , 0 0 0 . 0 0}$ \\
\hline 5 & Gross revenue (GR) (from 200 birds at N3,500 per bird) & $\mathrm{N} 700,000.00$ \\
\hline 6. & Returns to management (GR-TC) & $\mathrm{N} 444,000.00$ \\
\hline 7. & Benefit cost ratio $(\mathrm{GR} / \mathrm{TC})$ & 0.60 \\
\hline
\end{tabular}


Ugbe, Lawrence A., Ukelina, Christopher U., Agim, Marcel U., and Unim, Mathias U.:

Comparative analysis of the economic returns to management in single crop, fish, poultry and an integrated farming system in Obudu, Cross River State

Table 5: cost of production of rice, fish, poultry in an integrated farming system in 2019, and the economic returns to investment from each of them as influenced by the market price per unit of the products from the different farms

\begin{tabular}{|c|c|c|c|c|}
\hline & & Rice & Fish & Poultry \\
\hline $\mathbf{S} / \mathbf{N}$ & Production variables & \multicolumn{3}{|c|}{ Cost } \\
\hline 1. & Land preparation & $\mathrm{N} 12,000.00$ & - & - \\
\hline 2 & $\begin{array}{l}\text { Cost of planting materials (paddy } \\
\text { rice) }\end{array}$ & N70,000.00 & - & - \\
\hline 3. & Cost of sowing (broadcasting) & N6,000.00 & - & - \\
\hline 4. & Cost of transplanting seedlings & $\mathrm{N} 15,000.00$ & - & - \\
\hline 5. & $\begin{array}{l}\text { Cost of herbicides ( } 7 \text { bottle at } \\
\mathrm{N} 3,500.00 \text { per bottle) }\end{array}$ & $\mathrm{N} 24,500.00$ & - & - \\
\hline 6. & Cost of herbicide application & $7,000.00$ & - & - \\
\hline 7. & Cost of fertilizers & - & - & - \\
\hline \multirow[t]{2}{*}{8} & Cost of insecticides/application & & & \\
\hline & & $\mathrm{N} 13,000.00$ & - & - \\
\hline 9. & Cost of harvesting & $\mathrm{N} 8,000.00$ & N3,000.00 & - \\
\hline 10. & Cost of processing & $\mathrm{N} 10,000.00$ & $\mathrm{~N} 5,000.00$ & - \\
\hline 11. & $\begin{array}{l}\text { Cost of procurement of } 2000 \\
\text { fingerlings (at N35,000.00 per one) }\end{array}$ & - & N70,000.00 & - \\
\hline 12a. & $\begin{array}{l}10 \text { bags of } 1.5 \mathrm{~mm}(5,000.00 \text { per } \\
\text { bag) }\end{array}$ & - & N50,000.00 & - \\
\hline b. & $\begin{array}{l}10 \text { bags of } 2.0 \mathrm{~mm}(\mathrm{~N} 6,500 \text { per } \\
\text { bag) }\end{array}$ & - & $65,000.00$ & - \\
\hline c. & 25 bags of $6.0 \mathrm{~mm}(7,500$ per bag $)$ & - & $187,500.00$ & - \\
\hline d. & 50 bags of $9.0 \mathrm{~mm}(8,500$ per bag $)$ & - & $425,000.00$ & - \\
\hline 13. & $\begin{array}{l}\text { Cost of } 200 \text { day old chicks at N700 } \\
\text { per chick) }\end{array}$ & - & & N140.00.00 \\
\hline 14 & Feeds & - & - & - \\
\hline a. & $\begin{array}{l}\text { Starter marsh }(\mathrm{N} 3,000.00 \text { per bag } \\
\text { for } 10 \text { bags) }\end{array}$ & - & - & $\mathrm{N} 30,000.00$ \\
\hline b. & $\begin{array}{l}\text { Growers marsh (at N3,000.00 per } \\
\text { bag for } 20 \text { bags) }\end{array}$ & - & - & N60,000.00 \\
\hline c. & $\begin{array}{l}\text { Finishers (at N3,500.00 per bag for } \\
15 \text { bags) }\end{array}$ & - & - & N52,000.00 \\
\hline 15 & Vaccines & - & - & $\mathrm{N} 20,000.00$ \\
\hline 16. & Saw dust & - & - & $\mathrm{N} 2,000.00$ \\
\hline 17. & Miscellaneous & N15,000.00 & $\mathrm{N} 20,000.00$ & $\mathrm{~N} 20,000.00$ \\
\hline 18. & Total cost (TC) & N185,500.00 & N825,500.00 & N324,500.00 \\
\hline 19. & Yield in kilogramme (kg) & 500 & $1 \mathrm{~kg}$ weight & - \\
\hline 20 & Yield in $\mathrm{kg} / \mathrm{ha}$ & 1000 & - & - \\
\hline 21 & Gross Revenue (GR) & $\mathrm{N} 3,000,000.00$ & $\mathrm{~N} 2,062,000.00$ & N776,000.00 \\
\hline 22. & Returns to investment (GR-TC) & $2,814,500$ & $\mathrm{~N} 1,236,500.00$ & $\mathrm{~N} 451,500.00$ \\
\hline 23. & Benefit cost ratio $(\mathrm{GR} / \mathrm{TC})$ & 16.1 & 2.4 & 2.3 \\
\hline
\end{tabular}

Note:

i. Miscellaneous for rice are expenses on weeding, feeding and transportation while for fish and poultry they are expenses on feeding, transport and security

ii. Gross revenue for rice is yield ( $\mathrm{kg} / \mathrm{ha}) \mathrm{x}$ unit price of rice per $100 \mathrm{~kg}$ bag $(\mathrm{N} 70,000.00)$

iii. Gross revenue for fish is number of kilogrammes of fish $\mathrm{x}$ unit price per $\mathrm{kg}(\mathrm{N} 1,200.00)$

Yield of rice in $\mathrm{kg} / \mathrm{ha}=10,000(1$ hectare $)$

Plot area in sqm (100 x 50m) $\mathrm{x}$ plot yield in $\mathrm{kg}$

iv. Gross revenue from poultry $=$ No. of birds (194) $x$ unit price of each bird $(\mathrm{N} 4,000.00)$ 
Ugbe, Lawrence A., Ukelina, Christopher U., Agim, Marcel U., and Unim, Mathias U.:

Comparative analysis of the economic returns to management in single crop, fish, poultry and an integrated farming system in Obudu, Cross River State

Table 5 shows the computation of economic returns to management in an integrated farming system where rice was cultivated at the same time with rearing fish and poultry on the same plot. The returns to investment for rice cultivation was highly significant $(\mathrm{P}=0.01)$ as the cost of production was less than the returns. Also the returns to investment on fish was highly significant $(\mathrm{P}=0.01)$ as the total cost of production was far less than the returns from the investment. The returns on investment from poultry was equally significant $(\mathrm{P}<0.05)$ as the cost of production was less than the returns.

\section{Discussion}

The economic returns to management in the cultivation of rice as single investment was not significant, as the cost of production which was three hundred and two thousand, five hundred $(\mathrm{N} 302,500)$ naira was higher than the returns to investment which was two hundred and ninety seven thousand, five hundred naira N297,500.00) only. This fell short of making any gain, the reason for the low returns to investment was that much money was spent on procuring the inputs such as the rice paddy, herbicides, fertilizers and insecticides thereby giving a higher value for Total Cost (TC). The low yield of only 400 $\mathrm{kg} / \mathrm{ha}$ per hectare also affected the returns to investment. This may be attributed to the excessive rains that were recorded in the year 2016. This is in line with the observations of Udoh et al. (2005) that the mechanical effect of high rainfall especially during flowering and the cloud covering have negative impact (poor seeding, poor gain filling, formation of empty glumes etc) on rice production.

Returns to investment in fish production as single enterprise was also not significant $(\mathrm{P}>0.05)$ as the cost of production was one million, six hundred and eight thousand $(\mathrm{N} 1,608,000)$ far greater than the gross revenue which was nine hundred and seventy nine thousand, ninety nine naira (N979,99.00) giving a deficit of six hundred and twenty eight thousand, eight naira (N628,008.00) only, this fell short of any gain making. The deficit in the returns to investments was attributed to huge money expended in procuring feeds which were very expensive. The fish needed to be well fed in order that they produce higher yield. This is in line with the views of Akombo et al. (2015) that in fish culture, attention is usually given to factors such as breeding of the fish seeds, proper feeding, and controlled harvesting.

The returns to investment in poultry production as single enterprise investment was not significant $(\mathrm{P}>0.05)$ as the cost of production which was one million, one hundred, and forty four thousand naira $\mathrm{N} 1,144.000 .00)$ only, was far higher than the Gross revenue of eight hundred and five thousand naira $(\mathrm{N} 805,000.00)$ thereby giving a deficit returns to investment of minus three hundred and thirty nine thousand naira $(\mathrm{N}$ 339,000.00) only. Much of the expenditure was on the construction of the poultry house. However, the cost of feeds also weighed heavily on the total cost of production thereby resulting in low revenue as return to investment. The low gross revenue from the poultry farm in 2018 was also attributed to the high mortality rate arising from the outbreak of Avian influenza (H5NI) which claimed 50 birds of the 250 birds that were stocked giving $25 \%$ mortality rate. This was in accordance with the report of Food and Agriculture Organization -FAO (2018) which has it that global production of poultry in 2011 to 2016 was over 50 billion and 66 billion poultry birds respectively, but that the number dropped to 23 billion birds by 2018 due to outbreak of Avian influenza (H5NI) and mutation strains which came from China and affected over $13.6 \%$ of world's poultry supply. 
Ugbe, Lawrence A., Ukelina, Christopher U., Agim, Marcel U., and Unim, Mathias U.:

Comparative analysis of the economic returns to management in single crop, fish, poultry and an integrated farming system in Obudu, Cross River State

There was a significant $(\mathrm{P}<0.05)$ gain made in the establishment of an integrated farming system, where rice was cultivated, alongside with rearing fish and poultry on the same plot of land. In rice production, the total cost of production was as low as one hundred and eighty five thousand, five hundred naira N185,500.00), while the returns to investments was significantly $(\mathrm{P}<0.05)$ as high as two million, eight hundred and fourteen thousand, five hundred naira (N2,814,500.00). The cost-benefit from the production of a commodity is usually determined by the overall gain from the sales of the commodity with its production cost (CIMMYT, 1988). The interaction between the cost of production and the economic returns is however significant $(\mathrm{P}<0.05)$ in the production of rice in an integrated farming system. This is greatly attributed to the fact that less of fertilizers were bought to enrich the soil for the rice production. The rice plants were planted right inside and within the environment of the fish ponds and were deriving about $60 \%$ of their nutrients from the ponds, so less of the synthetic fertilizers were required. This was in agreement with Nnaji et al. (2003) who reported that in integrating fish with rice cultivation, the crops derived water and nutrients from the fish ponds, while the crops serve as food, especially for herbivorous fish. The silt produced in the fish supplied fertilizer for the rice plants thereby reducing the need for synthetic fertilizers and at the same time reduced cost of production. This was in line with Ayinla (2003) who reported that the silt from fish pond is used to fertilize crops in an integrated system thereby increasing yield and lower the cost of production and the need to buy synthetic fertilizers.

Economic returns to investment in integrated fish production was highly significant $(\mathrm{P}=0.01)$ as the total cost of production was eight hundred and twenty five thousand, five hundred naira $(825,500.00)$ only, while the gross revenue was two million, sixty two thousand naira (N2,062,000.00) only, giving a return to investment of one million, two hundred and thirty six thousand, five hundred naira $(\mathrm{N} 1,236,500.00)$ only, this significant returns to investment was also attributed to the use of low cost inputs arising from the recycling of waste products. Poultry dungs were used to promote the growth and productivity of phyto and zooplankton which the fish fed on. Due to the short digestive tract of poultry, $80 \%$ of chicken manure represents undigested feed stuffs with as high as 20-30\% being total protein (Chen, 1989). This is also in agreement with Oladosu, Ayinla, Onuoha and Mecdon (1990) who reported that in targeted poultry cum fish faming, the protein rich chicken dropping is made available to the fish either directly or indirectly via the primary producers in the aquatic food web, this in most cases reflects the productive capacity of the pond. By reducing the cost of fertilizers and feedstuffs the overall cost of fish production was reduced so the profit increased.

The returns to investment in integrated poultry production was significant $(\mathrm{P}<0.05)$ as the production cost was less than the returns to investment. The total was three hundred and twenty four thousand, five hundred naira $(\mathrm{N} 324,500.00)$ only, while the gross revenue was seven hundred and seventy six thousand naira (N776,000.00) only. Returns to investment was four hundred and fifty one thousand, five hundred naira (N451,500.00) only. The significant returns to investment was attributed to a reduction in the production cost following the use of low cost inputs. When rice was harvested and processed, the rice bran were used as feed for the poultry. Also when fish were harvested and some processed, fish waste were further processed and fed to the poultry in a complementary enterprise relationship. By reducing the overall cost of production in this 
Ugbe, Lawrence A., Ukelina, Christopher U., Agim, Marcel U., and Unim, Mathias U.:

Comparative analysis of the economic returns to management in single crop, fish, poultry and an integrated farming system in Obudu, Cross River State

method, the profit was increased. The poultry integrated with fish culture happens to be the commonest system of integration in Nigeria because of its profitability. This is supported by the views of Tokrisna (1995) that the most common integrated practice in Nigeria is fish cum chicken, which is widely practiced because of its profitability. He further added that this method reduces the cost of inputs, such as fertilizer and feed, so as to maximize profits.

The economic benefits of integrated rice, fish and poultry farming are enormous. Its enhancement of food production and selfsufficiency of the farmer is great. Apart from rice, other vegetable crops could be planted along side in most integrated farms. The significance of making various types of food available all year round as well as making farmers self reliant and occupied most time of the year, makes it stand out as the best of all farming systems. The system encourages organic agriculture and reduce the use of synthetic chemicals in agricultural production. It has ecological importance which often times are over looked by the farmers, these are manure loading, nutrient cycling and productive capacity of the farms. This ecological consideration of the integrated system is of paramount importance, in that it allows recycling and maximum utilization of resources without wastage.

\section{Conclusion}

Integrated farming is better and more cost effective and profit oriented than the single enterprise of rice only, or poultry or fish culture only, since the items produced are to be used either as a source of feed, fertilizer or source of additional income. Its relevance reflects on the livelihood of every segment of the Nigeria population in the provision of food, employment opportunities and recirculation of waste for maximum utilization. The supply of food in Nigeria especially protein food is an important task that must be taken seriously, and integrated farming offers hope in this direction, considering the limited available resources. Integrated farming serves as food production base that combines cultivation of crops, rearing livestock and fish farming. The integrated fish, poultry and rice/vegetable farm supplies not only enough fertilizer to produce a large quantity of fish, but also produces meat, eggs, vegetables etc, as it fully utilizes the water body, the water surface, the land, and the pond silt to increase the food available for human consumption. Integrated farming is most suitable for poor farmers with remarkable low expenditure pattern and continuous low spending for food and other dietary requirements. The varied nature of integrated farming makes more jobs available than in unitary system or single enterprise. The system is all encompassing as the time is well utilized depending on the type of integration involved.

Based on the result of the experiment conducted here, the paper recommended that:

i. The returns to investment in an integrated enterprise farming system was far greater than the one in single enterprise, therefore are encouraged to adopt the integrated farming system rather than the single enterprise especially where there is limited land.

ii. Special loan facility be created in agricultural loan schemes for farmers willing to engage in integrated farming system.

iii. The government should also assist integrated farmers with inputs such as fish feed, poultry feeds etc, at low cost in order to encourage them.

iv. Extension agents be employed and attached to each integrated farmer 
Ugbe, Lawrence A., Ukelina, Christopher U., Agim, Marcel U., and Unim, Mathias U.:

Comparative analysis of the economic returns to management in single crop, fish, poultry and an integrated farming system in Obudu, Cross River State

to assist the farmers in applying the basic principles involved in integrated farming appropriately.

v. The government should assist in creating the enabling market system and channels for the farmers to sell their produce at favourable prices in order to make profit.

\section{References}

AIFP, 2005. Farming Nigeria Water Newsletter of the Aquaculture and inland Fisheries Project of the National Special Programme for food security in Nigeria. FAO Office Abuja, Nigeria 3 (4): 2-4.

AIFP, 2011. Farming Nigeria Water Newsletter of the Aquaculture and inland fisheries project of the National Special Programme for Food security in Nigeria. FAO office Abuja, Nigeria 5(6): 5-8.

Akombo, P.M., Atile, J.I., and Shina, J.N., 2015. Fundamentals of Fisheries for schools and Colleges. Abuja: Kall Kwait Graphics.

Alders, R., Costa, R., Gallardo, R.A., Sparks, N., and Zhou, H., 2019 small holder poultry: Leveraging for sustainable food and nutrition security. Encyclopedia of food security and sustainability 3:340-346.

Asala, G., 1994. Principles of Integrated Aquaculture. In A.A. Olatunde (eds). Conference proceedings of fisheries society of Nigeria, Querri, Nigeria. Pp. 48-52

Ayinla, O.A., 2003. Integrated fish farming: A veritable tool for poverty alleviation/Hunger eradication in the Niger Delta Region. In A.A. Ayo and J.O. Atanda, (eds). Conference proceedings of Fisheries society of Nigeria, Owerri, Nigeria. Pp. 40-42.
Carbolla, E., Van Ecr A., Schie, Ton Van, Hibbrands, A. and Odey, J.A., 2018. Small scale fresh water fish farming. Fisheries consultancy services. New Bussa, Niger State.

Chen, F.Y., 1989. Chicken farming in integrated fish farming. Regional Aquaculture centre. Wuxi China: NACH Technical Manual 11:4-30.

CIMMYT, 1988. From Agronomic Data to Farmers Recommendations and Economic Training Manuel. International Maize and Wheat Improvement Centre, Mexico, D.F., 33: $16-70$.

Dilger, A.C., Schroeder, A.L., and Moseky, W.M., 2016. Barriers to global implementation of current and development of new performance enhancing technologies in meat production. Frontiers, 6 (4): 50-55.

FAO, 2008. Food and Agriculture Publication, Year Report 2002 FAO, Rome Pp. 1-6.

FAO, 2018. Africa sustainable livestock 2050: Livestock and livelihoods sport light. Nigeria. Cattle and poultry sectors. Available at: http://www.fao.org./3/CA2149EN/Ca 2149en.pdf. Accessed on the $15^{\text {th }}$ March 2020.

FMARD, 2007. Aquaculture Transformation Action Plan, Federal Ministry of Agriculture and Rural Development Abuja. August 5, 2007.

FMARD, 2011. Aquaculture Transformation Action Plan. Federal Ministry of Agriculture and Rural Development, Abuja, September 9, 2011.

Huazhu, Y. and Baotany, K., 1989. Integrated fish farming in china. Bangkock, Thailand: Naca Technical Manual.

National Bureau of Statistics (2018). Rice production in Nigeria, NBS, AbujaNigeria. 
Ugbe, Lawrence A., Ukelina, Christopher U., Agim, Marcel U., and Unim, Mathias U.:

Comparative analysis of the economic returns to management in single crop, fish, poultry and an integrated farming system in Obudu, Cross River State

Nnaji, C.J., Okoye, F.C., Ogunseye, J.O., 2003. Integrated fish farming practices with special reference to combination rates production figures and economic evaluation, In: A.A. Eyo, J.O. Ayanda (eds). Conference proceedings of fisheries society of Nigeria (FISON) Owerri, $8^{\text {th }}-12^{\text {th }}$ December, 2003. Pp. 173-178.

Oladosu, G.A., Ayinla, O.A., Onuaha, G.C., Mecdom, J.G., 1990. Performance of clarias gariepinus in a polyculture with orechronics riloticus under the integrated broiler chicken fish farming. NIOMR Technical/paper P. 65.

Ritchie, H., and Roser, M., 2020. "Meat and Dairy production. Published online at Our World in Data. Org. 'Available at https://ourworldindata.org/meatproduction? Accessed on the $5^{\text {th }}$ March 2020.
Tokrisna, R., 1995. Integration of Agriculture, livestock and fish farming in Thailand. In J.J Symoens and J.C. Micha (eds). RAOS/CTA.FAO Seminar proceedings 1995. Pp. 245-263

Udoh, D.J., Ndon, B.A., Asuquo, P.E. and Ndaeyo, N.U., 2005. Crop production Techniques for the Tropics. Lagos: concept publishers.

Wahyono, N.D., and Utami, M.D., 2018. A review of the poultry meat production industry for food Safety in indomesia. Journal of physics conference series. 953 (1): 121-125.

World Economic forum, 2019. Meat: the future series options for the livestock sector in Developing Emerging Economies to 2030 and Beyond. Available at: http://www 3. Weforum.org/docs/white paper livestock emerging \% 20 Economics. Pdf. Accessed on the $15^{\text {th }}$ March, 2020. 